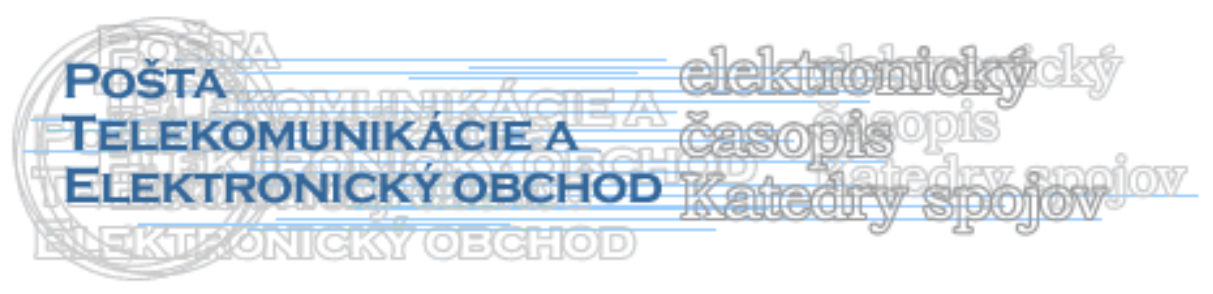

\title{
CRM PROCESY A MOŽNOSTI ICH INFORMATIZÁCIE
}

\author{
Ing. Milan Kubina, PhD., Ing. Viliam Lendel*
}

\section{Úvod}

Dynamický vývoj trhu a rozvoj nových informačných technológií je výzvou pre všetky spoločnosti. Stále však platí, že pre úspešné podnikanie je najdôležitejšia schopnost' vyrábat' a predávat' efektívne. To znamená vyrábat' a predávat' práve tie produkty a služby, ktoré uspokoja potreby zákazníka. Ako však zákazníka nájst', oslovit', získat' a hlavne ako si ho v silnej konkurencii udržat'?

Riadenie vzt’ahov so zákazníkmi je súhrnom marketingových, komunikačných, obchodných a servisných procesov $\mathrm{v}$ podniku podporovaných vhodnou organizačnou štruktúrou a technológiami, ktoré umožňujú cielene riadit' vzt’ahy so zákazníkmi a prispôsobovat' ponuku podl'a ich potrieb a želaní. Tieto vzt'ahy majú priamy vplyv na racionalizáciu, optimalizáciu a celkové zefektívnenie všetkých činností, ktoré súvisia s týmito vzt'ahmi.

Základnou súčast'ou riadenia vzt’ahu so zákazníkmi je integrované chápanie procesov marketing, predaj a služby. Ohraničenie procesov marketing, predaj, služby sa týka ciel'ových skupín procesných aktivít, ako aj udalostí kontaktovanie zákazníka a uzatvorenie zmluvy. Aby sa prejavil celý potenciál CRM, musí sa zabezpečit’ plynulý informačný tok medzi týmito procesmi. Efektívnost' procesov CRM podporujú riešenia IT. Základnou súčastou riešenia CRM je dátový sklad a aplikácie umožňujúce triedenie a analýzu zákazníckych údajov. Klúčovou otázkou je previazanost' všetkých komponentov systémov CRM (operatívna, analytická a kolaboratívna zložka) a integrácia s ostatnými podnikovými systémami a procesmi, ako aj definovanie komunikačných kanálov so zákazníkmi (osobný kontakt, telefón, internet atd'.). [7]

Najvýznamnejším komunikačným a predajným kanálom sa stáva internet. Podnik by tak mal dosiahnut' ucelený pohl'ad na zákazníka, ktorý očakáva, že všetky komunikačné kanály sú rovnocenné a že o všetkých jeho prechádzajúcich kontaktov $\mathrm{s}$ firmou budú zamestnanci vediet'.

\section{CRM procesy}

Ciel'om základných aktivít CRM je identifikácia a neustála aktualizácia podnikových procesov, ktoré súvisia so zákazníkom a ktoré prostredníctvom svojich aktivit realizujú

\footnotetext{
* Ing. Milan Kubina PhD., Ing Viliam Lendel, Katedra manažérskych teórií, Fakulta riadenia a informatiky, Žilinská Univerzita, Univerzitná 1, 01026 Žilina, milan.kubina@fri.uniza.sk, viliam.lendel@fri.uniza.sk
} 
príslušný obchodný model podniku. Obchodný model má slúžit' k porozumeniu logiky vytvárania hodnoty podniku a k vymedzeniu obchodného priestoru. Obchodný model je teda strategickým nástrojom, ktorý zohl'adňuje situáciu konkurencie, zákazníkov, partnerov a možné formy spolupráce. Strategický ciel' obchodného modelu je zrejmý, je to schopnost' poskytnút požadované riešenie danému zákazníkovi pri minimalizácii vlastných nákladov. [3]

Proces je už konkrétnym realizátorom aktivít v rámci príslušného obchodného modelu. Proces je základnou jednotkou riadenia a hodnotenia a ako taký musi mat' definovaného minimálne svojho vlastnika, obsah, metriky a zdroje. Procesy CRM sa delia do troch hlavných skupín. Sú to procesy marketingu, obchodu a služieb. [3]

Zjednocujúcim hl'adiskom návrhu obchodného modelu a odpovedajúcich procesov sa v súčasnosti stáva zákazník.

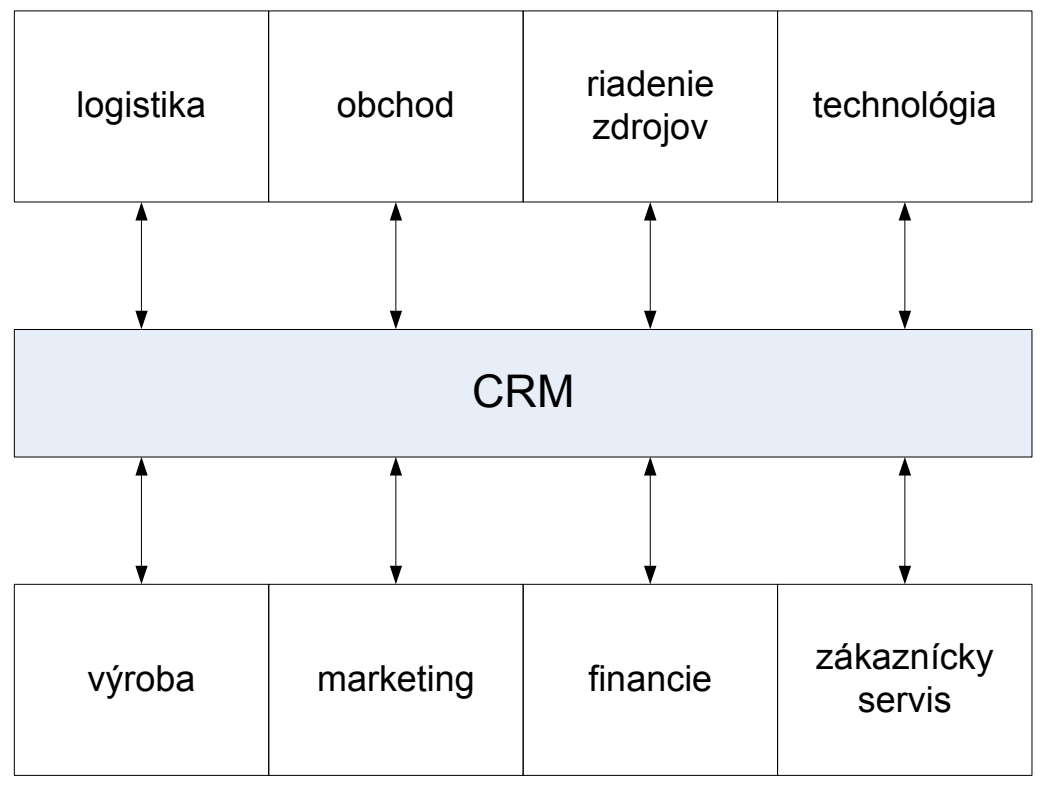

Obrázok 1 Väzba CRM na podnikové funkcie

Procesy CRM sú charakteristické vysokou intenzitou znalostí, komplexnost'ou a variabilitou, uplatňujú sa sekvenčne so vzájomným prelínaním v závislosti od špecifických situácií, ktoré nastanú v obchodnom cykle. Zmena podnikových procesov sa musí realizovat' pod dohl'adom a súčinnou podporou vrcholových riadiacich pracovníkov. Splnenie tejto zásadnej a nevyhnutnej podmienky vytvorí predpoklady, aby zamestnanci mohli konat' novým spôsobom a tvorivo rozvíjat' nové procesy, ktorými sa sleduje tvorba hodnoty pre zákazníkov. [1] 
Tabul'ka 1 Podnikové procesy so vzt’ahom k CRM zodpovedajúce príslušnej podnikovej funkcii

\begin{tabular}{|c|c|}
\hline Podniková funkcia & Podnikové procesy so vzt’ahom k CRM \\
\hline MARKETING & $\begin{array}{ll}\text { - } & \text { distribúcia reklamných a informačných materiálov } \\
\text { priamo k zákazníkom, } \\
\text { - } & \text { výber ciel'ových zákazníkov, } \\
\text { - } & \text { akvizícia nových zákazníkov, } \\
\text { - } & \text { riadenie marketingových kampaní, } \\
\text { - } \quad \text { riadenie príležitostí. }\end{array}$ \\
\hline OBCHOD & $\begin{array}{l}\text { zmluvné vzt’ahy, } \\
\text { prognózovanie predaja, } \\
\text { riadenie kontaktov so zákazníkmi. }\end{array}$ \\
\hline $\begin{array}{l}\text { ZÁKAZNÍCKY } \\
\text { SERVIS }\end{array}$ & 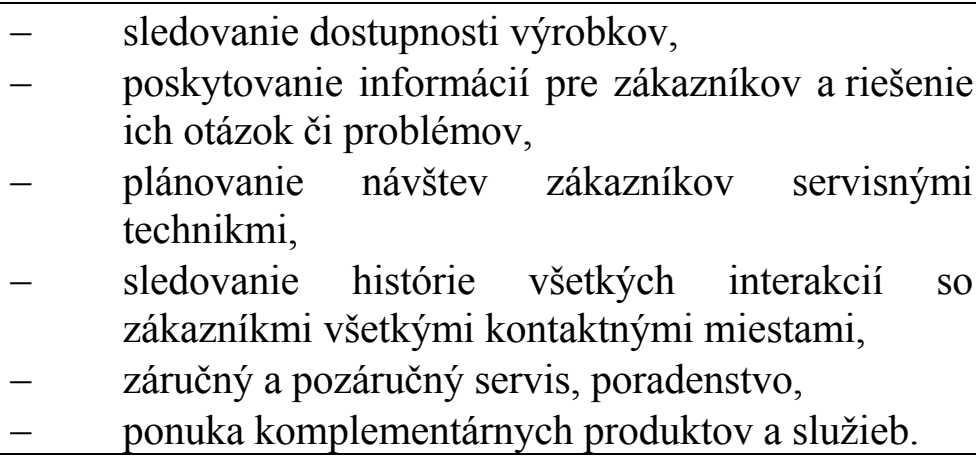 \\
\hline TECHNOLÓGIA & $\begin{array}{ll}\text { - } & \text { komunikácia so zákazníkom v oblasti výmeny } \\
\text { informácií, } \\
\text { - } & \text { vybavenie požiadaviek zákazníkov, } \\
\text { - } & \text { obsluha a podpora zákazníkov, } \\
\text { - } & \text { analýzy výsledkov predchádzajúcich procesov, } \\
\text { - } & \text { trhové analýzy, sledovanie komunikácie. }\end{array}$ \\
\hline LOGISTIKA & $\begin{array}{l}\text { logistické služby spojené s dodávaním, } \\
\text { realizácia dodávky produkty a služieb, } \\
\text { fakturácia, sledovanie inkasa. }\end{array}$ \\
\hline FINANCIE & 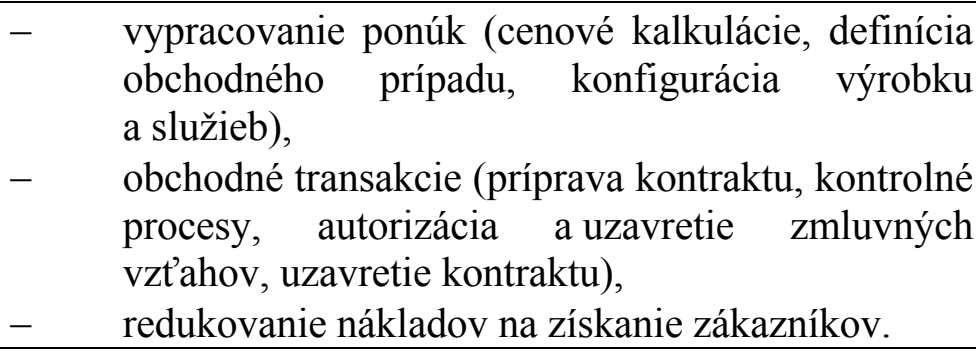 \\
\hline
\end{tabular}

\section{CRM systémy}

V určitom okamihu kvantitatívneho rastu objemu obchodov a počtu zákazníkov musia vstúpit' do procesu budovania vzt’ahov medzi zákazníkmi a dodávatel'mi informačné a komunikačné technológie.

Podobne ako ostatné moduly informačných systémov aj CRM možno vybudovat' ako súčast' vlastného informačného systému, ktorý beží na firemnom serveri. 
V posledných rokoch bol zaznamenaný značný záujem o tieto informačné systémy zamerané na riadenie vzt’ahov so zákazníkmi, ktoré ako praktický nástroj slúžia marketingovým a obchodným oddeleniam. CRM nie sú určené len pre evidenciu klientov, zákaziek a štatistický reporting, ale hlavne umožňujú zefektívnit' celý proces komunikácie so zákazníkom, vybavovanie požiadaviek, automatizujú rozhodnutia a ponúkajú v rámci obchodnej filozofie firmy rôzne strategické nástroje pre lepšie pritiahnutie a udržanie si zákazníkov na základe ich detailného poznania. CRM systémy majú silné analytické nástroje, ktoré slúžia na hl'adanie odpovedí napríklad na otázky typu: [6]

- ktorých klientov oslovit' pri zavedení nového produktu alebo služby s vysokou pravdepodobnost'ou úspešnosti oslovenia,

- aký je profil jednotlivých segmentov klientov,

- aký je profil najziskovejších a najstratovejších klientov,

- aká je reakcia klientov na zmenu cien a služieb,

- ako segmentovat' klientov za účelom vytvorenia vernostného systému,

- ktoré marketingové nástroje sú najúspešnejšie,

- ktoré distribučné kanály sú najefektívnejšie,

- atd'.

Prínos CRM systému do firmy má dve stránky:

- na jednej strane ide o výrazné ul'ahčenie a zefektívnenie obchodných procesov, čo prináša úsporu nákladov a šetrenie času,

- na druhej strane zvyšujú účinnost' marketingových aktivít ich správnym zameraním, čo prináša do spoločnosti väčšie tržby.

\section{Technologická architektúra}

Pri budovaní CRM systémov sa najviac využíva trojvrstvová architektúra klient/server. Prvú vrstvu tvorí databázový server, pre uchovávanie dát $\mathrm{v}$ databáze. Najčastejšie využívané databázy pri budovaní CRM systémov v súčasnosti sú napr. Oracle databáza, MS SQL server, MySQL, atd'. Druhú vrstvu tvorí aplikačný server pre aplikačné programy, ktoré v sebe zahŕňajú samotnú logiku celého aplikačného systému. Programujú sa zväčša v niektorom procedurálnom programovacom jazyku ako: PHP, ASP, Java, atd'. Tretiu vrstvu trojvrstvovej architektúry predstavuje používatel'ské rozhranie, ktoré slúži na komunikáciu systému s používatel'om. Najčastejšie sa využíva komunikácia so systémom prostredníctvom internetového prehliadača.

\section{Moduly a funkcionalita}

CRM systémy sa skladajú z viacerých modulov, ktoré zabezpečujú celý marketingový a obchodný cyklus podniku. Každý modul obsahuje množinu funkcionality, ktorá rieši jednotlivé úlohy a kroky tohto cyklu. Ako základné moduly a ich funkcionalitu CRM systémov môžeme spomenút': [6]

- Riadenie kontaktov: pridávanie, kategorizácia a vyhl'adávanie kontaktov, export a import kontaktov, segmentácia klientov,

- Marketing: evidencia marketingových aktivít, sledovanie účinnosti marketingu, automatizácia niektorých marketingových aktivít (automatické rozosielanie emailov, sms pod.), 
- Riadenie predaja: generovanie ponúk, riadenie distribučných kanálov, príjem a spracovanie objednávok, komunikácia so skladom, generovanie a odosielanie faktúr,

- Služby zákazníkom: servis, support, generovanie výpisov a informácií, riadenie reklamácií,

- Analýza a spravodajstvo: reporting, predajné štatistiky, pracovné výkazy, sumárne prehl'ady obchodu.

\section{Aplikačná architektúra}

Aplikačnú architektúru CRM systémov (obrázok 2) je možné rozdelit’ na tri časti: [6]

- Komunikačnú čast' CRM systémov využíva front office, jej úlohou je riadit' distribučné kanály a zabezpečovat' tok informácií medzi zákazníkom a organizáciou ako napr. reklama, oslovenie klienta, zasielanie ponúk, prijatie objednávok atd'. Medzi distribučné kanály patrí: call centrum, pobočky, obchodný zástupcovia, obchodný partneri, internet - web a email, mobilné zariadenia - sms a wap, pošta a d'alšie.

- Operačnú čast' CRM systémov využíva back office, jej úlohou je spracovávat' a riadit' celý marketingový a obchodný cyklus podniku ako napr. spracovat' objednávky, riadit' dodanie tovaru, fakturáciu, servis a pod.

- Analytickú čast' CRM systémov využíva manažment podniku, tvorí sa z výstupnej a vstupnej časti. Výstupná čast' vo forme reportov poskytuje pre manažment analytické a štatistické informácie, na základe ktorých manažment prijíma marketingové a obchodné rozhodnutia, ktoré tvoria vstupnú čast' analytickej časti CRM systému.

\section{Prehl'ad systémov CRM dostupných na slovenskom trhu}

Na našom trhu sa možno stretnút' s pestrou ponukou rôznych CRM riešení pre malé aj vel'ké firmy, z niektorých firiem a ich produktov možno spomenút': [5]

- ABRA G3 CRM (doplnok informačného systému ABRA G3),

- Cígler CRM S3 (doplnok k ekonomickému systému Money S3),

- Datalock CRM (doplnok informačného systému SPIN),

- FLEX CRM (doplnok informačného systému FLEX IS),

- Microsoft Dynamics CRM,

- Oracle, Peoplesoft a Siebel,

- SAS CRM,

- mySAP CRM (doplnok ERP systému SAP R/3). 


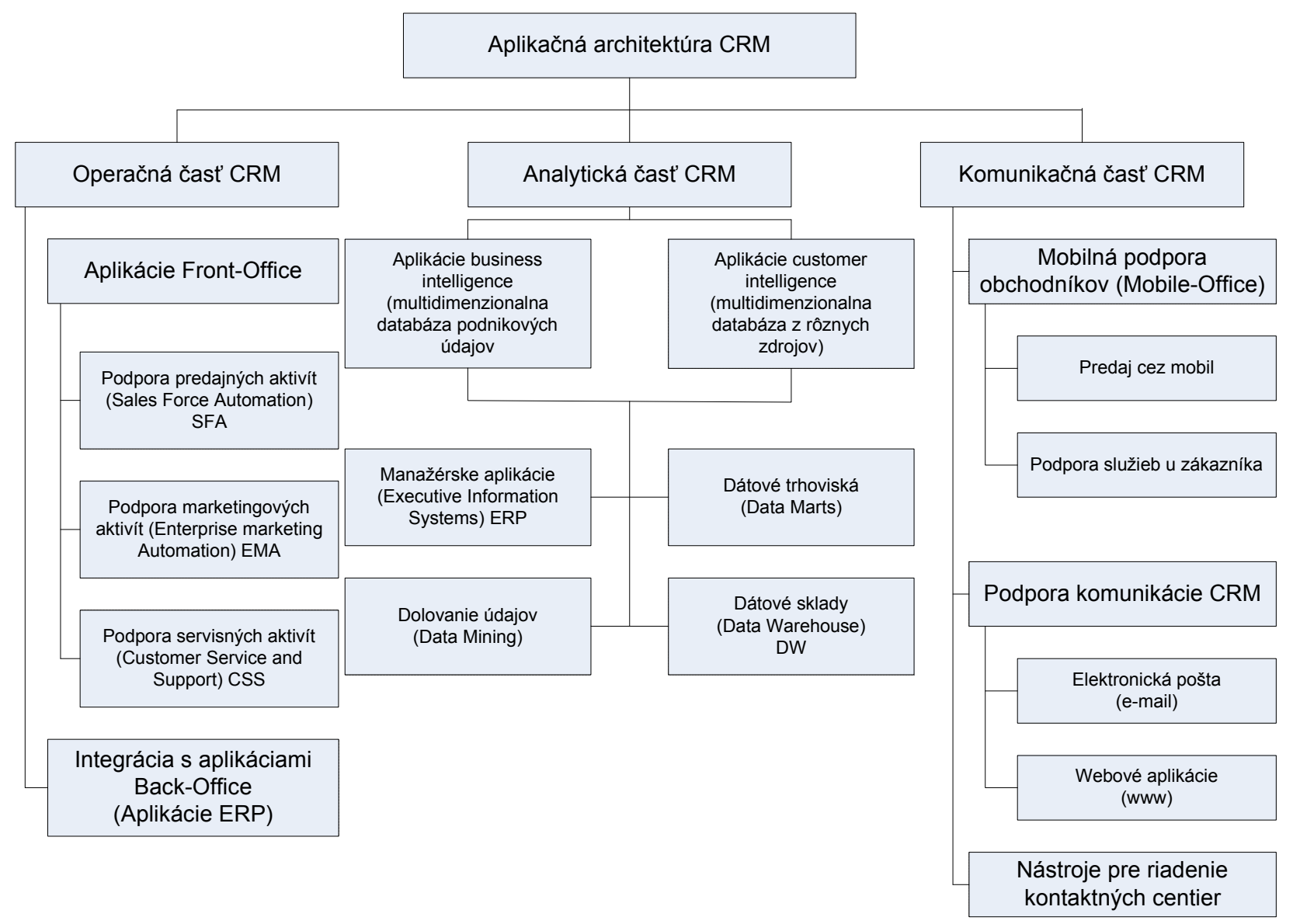

Obrázok 2 Aplikačná architektúra CRM [1]

\section{Informačné potreby vznikajúce pri uplatňovaní CRM}

Je potrebné vybudovat' systém, ktorý všetkým účastníkom vzt’ahu umožní prístup $\mathrm{k}$ informáciám, ktoré potrebujú, aby mohli splnit' svoje role. V ideálnom prípade by mal byt' systém konštruovaný tak, aby umožnil automatický prístup k požadovanej informácii a automaticky ukladal údaje o zákazníkoch. Vol'ný pohyb informácií medzi funkciami je nevyhnutný pre riadenie údajov o vzt'ahoch so zákazníkmi [2]. Úlohou tímu je zhromažd’ovat' poznatky o zákazníkoch v rámci vlastných vzt'ahov a kontinuálne rozvíjat' stratégie vzt’ahov so zákazníkmi. (obrázok 3). 


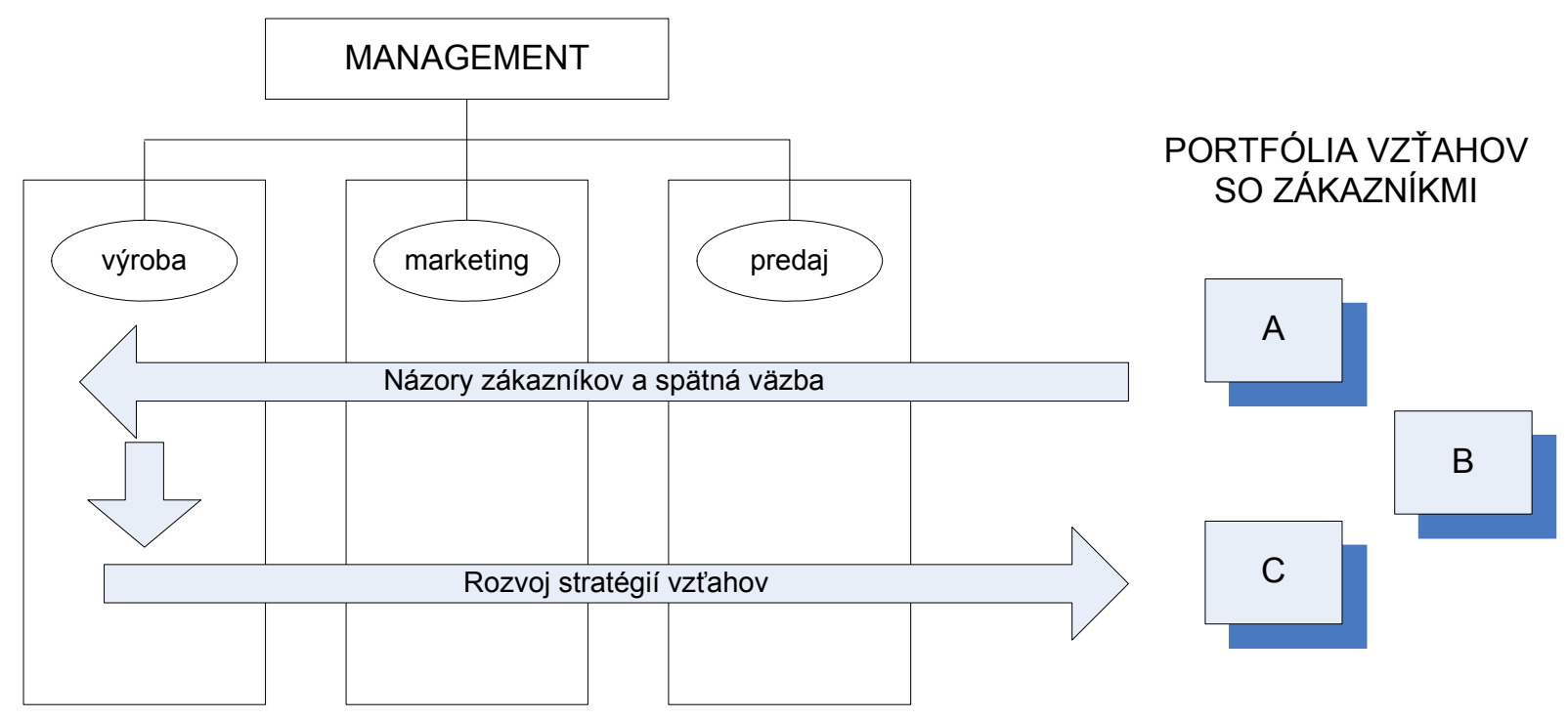

Obrázok 3 Riadenie údajov o vzt’ahoch so zákazníkmi [2]

\section{Záver}

Dynamický trh, konkurenčné prostredie, meniace sa potreby zákazníkov a rýchly vývoj IT vytvárajú priestor pre prínos nových a efektívnych nástrojov prinášajúcich firmám väčší zisk. CRM systémy ponúkajú tieto nástroje ako kombináciu najnovších IT technológií a marketingovej filozofie. O lukratívnosti týchto systémov svedčia aj kroky spoločnosti Oracle, ktorá za posledné roky kúpila dvoch silných hráčov na trhu spoločnost' Siebel a Peoplesoft, ktoré boli významným dodávatel'om týchto riešení. Týmto spoločnost' Oracle získala najsilnejšie postavenie na trhu v kategórií CRM systémy pre vel'ké podniky. V riešeniach pre vel'ké firmy sú väčšinou CRM systémy súčast'ou komplexných ERP podnikových riešení ako jeden $\mathrm{z}$ ich modulov. $V$ riešeniach pre menšie firmy sú to väčšinou samostatné aplikácie, čo je výhoda pre tieto menšie firmy, ktoré nepotrebujú rozsiahle informačné systémy pre chod celej spoločnosti, ale potrebujú pokryt' iba práve oblast' obchodu a komunikácie so zákazníkmi.

\section{Literatúra}

[1] DUDINSKÁ, E., NOVOTNÁ, L., DROPPA, M. 2006. Riadenie vztahov so zákazníkmi v globálnej ekonomike. Prešov: Vydavatel'stvo Michala Vaška, 2006..

[2] STORBACKA, K., LEHTINEN, JR. 2001. Řizení vztahů se zákazníky (Customer relationship Management). Praha: Grada, 2001.

[3] DOHNAL, J. 2002. Ř́zení vztahů se zákazníky. Procesy, pracovníci, technológie. Praha: Grada, 2002.

[4] LACKO, L. 2006. CRM Proces na rozhraní technológií a psychológie. In Infoware. ISSN 1335-4787, 2006, číslo 6, s. 28-29.

[5] VOJTECHOVSKÝ, J. CRM systémy - všeobecný pohlad. Dostupné na internete: http://vojtechovsky.blog.sme.sk/c/63746/CRM-systemy-vseobecny-pohlad.html

[6] MAJERČÁK, D. 2005. Architektúra informačných systémov procesného portálu pre prepravu a logistiku. Dostupné na internete: http://www.ikaros.cz/node/2038 